\title{
Yetiştirici Şartlarında Saanen x Kıl Melezi Keçilerinde Bazı Meme Ölçüleri ve Toplam Sağılabilir Süt Miktarı Arasındaki İlişkiler Üzerine Bir Araştırma
}

\author{
Şeniz ÖZİŞ ALTINÇEKİÇ \\ Mehmet KOYUNCU \\ Uludağ Üniversitesi Ziraat Fakültesi Zootekni Bölümü, Bursa \\ $\bowtie$ :senizozis@gmail.com
}

Geliş (Received): 23.05.2016

Kabul (Accepted): 01.01.2017

\begin{abstract}
ÖZET: $\mathrm{Bu}$ araştırmada, Saanen x K1l keçisi F1 melezlerinde meme ölçüleri, toplam sağılan süt miktarı ve süt kompozisyonu incelenmiştir. Değerlendirilen veriler 2. ve 3. laktasyondaki 47 baş keçiden elde edilmiştir. Meme genişliği, meme çevresi, meme uzunluğu, iki meme başı arası açı ile toplam sağılan süt miktarı arasındaki korelasyonlar sirasiyla $0.598,0.662,0.574$ ve 0.497 olarak tespit edilmiştir $(\mathrm{P}<0.01)$. Sütün protein oranı ile toplam sağılan süt (0.293), laktoz (0.394) ve yağsız kuru madde (0.648) arasında pozitif korelasyon bulunduğu saptanmıştır $(\mathrm{P}<0.05 ; \mathrm{P}<0.01)$. Buna karşılık sütün protein oranı ile $\mathrm{pH}(-0.358)$ değeri arasında negatif bir korelasyonun olduğu belirlenmiştir $(\mathrm{P}<0.05 ; \mathrm{P}<0.01)$.
\end{abstract}

Anahtar sözcükler: Saanen x Kıl melezi, süt verim özellikleri, meme ölçüleri, fenotipik korelasyonlar

\section{A Research on Relationships between Some Udder Measurements and Total Milking-only Milk Amount of Saanen x Hair Goat Crossbreed in Breeder Conditions}

\begin{abstract}
In this study; udder measurements, total amount of milking and milk composition of Saanen x Hair goat $\mathrm{F}_{1}$ crossbreed were examined. The study data were obtained from 47 head goats in the 2nd and 3rd parity. Correlations between total amount of milking and udder width, udder circumference, udder length and angle between two teats were identified as $0.598,0.662,0.574$ and 0.497 , respectively $(\mathrm{P}<0.01)$. It was determined that there was a positive correlation between the protein rate of milk and total milking amount (0.293), lactose (0.394) and fat-free dry matter (0.648). Whereas a negative correlation was identified between the protein rate of milk and $\mathrm{pH}$ value $(-0.358)$ $(\mathrm{P}<0.05 ; \mathrm{P}<0.01)$.
\end{abstract}

Keywords: Saanen x Hair croosbreed goats, milk yield traits, udder measurements phenotypoic correlations

\section{Gİiş}

Hayvan yetiştiriciliğinde her yıl verim artışının sağlanmanın önemli koşullarından birisi, üstün nitelikli hayvanları sürüde tutarak bunlardan döl almaktır. Bu amaca yönelik olarak süt keçisi yetiştiriciliğinde damızlık seçimi için yetiştirici doğrudan verim kayıtlarından ve dış yapı özelliklerinden yararlanır. Süt keçilerinde memenin hacimli ve vücuda bağlantısının güçlü olması yüksek süt veriminin bir işareti olarak kabul edilir. Laktasyon süt verimi ile meme çevresi, hacmi, genişliği, uzunluğu, derinliği ve meme başları arası mesafe gibi meme ölçüleri arasında pozitif korelasyon olduğu bilinmektedir (Labussière ve ark., 1981). Süt keçiciliğinde meme yapısını tanımlayan özelliklere göre yapılan puanlama ve değerlendirmeler, verim denetimlerini tamamlamaya yardimc bir unsurdur (Şimşek ve ark., 2006)

Sütün kalitesi; kompozisyonu oluşturan protein, laktoz ve yă̆ içeriğine göre belirlenmektedir. Süt kompozisyonunun bilinmesi süt sanayi, keçi sütü ile yapılan ürünler ve pazarlama noktasında faydalar sağlayabilir (Petrovic ve ark., 2005). Süt parametrelerinden yararlanılarak fiyatlandırmanın oluşturulması temelinde, sütte ekonomik öneme sahip bileşenler üzerine değişik çevre koşullarının etkilerinin bilinmesi yanında Türkiye'de mevcut ırklar bazında referans değerlerin belirleneceği çalışmalara ihtiyaç duyulduğu ifade edilmektedir (Tekelioğlu ve ark., 2010).
Bu çalışmada Saanen x Kıl Fı melezi keçilerde meme ölçülerinin tespit edilmesinin yanı sıra toplam sağılan süt miktarı ile süt kompozisyonunun belirlenmesi, bunların birbirleri ile olan ilişkilerinin ve söz konusu sütlerin Türk Gıda Kodeksi Yönetmeliği’ne uygunluğunun ortaya konulması amaçlanmıştır.

\section{MATERYAL ve METOT}

\section{Hayvan Materyali}

Araștırma, Bursa ili Mustafakemalpaşa ilçesi Çeltikçi köyünde bulunan özel bir işletmede yürütülmüştür. Keçilerin sağımları makine ile sabah ve akşam olmak üzere günde iki kez, meraya çıkmadan önce yapılmıştır. Araştırma sürüsü Kıl keçilerine Saanen tekeler katmak suretiyle elde edilmiş olan $F_{1}$ düzeyinde, 2 . ve 3 . laktasyonda, $45-55 \mathrm{~kg}$ canlı ağırlıkta 47 baş melez keçiden oluşmaktadır. Keçiler hava koşullarına bağlı olarak yaklaşık yılın 10 ayını ve günde ortalama 7 saatini merada geçirmektedirler. Laktasyon döneminde meraya ilave olarak yonca kuru otu ( $0.8 \mathrm{~kg} /$ baş $)$ ve misır silajı (1 $\mathrm{kg} / \mathrm{baş}$ ) ile hayvan başına $750 \mathrm{~g}$ süt yemi verilmektedir. Hayvanlara daima temiz su ve mineral ihtiyaçlarının karşılanması için yalama taşı sağlanmıştır.

Toplam sağılan süt miktarının belirlenmesi

Keçiler, yavrular sütten kesildikten sonra (90. gün) sağılmaya başlanmıştır. İlk süt kontrolü yavruların sütten kesildiği gün yapılmış ve 15 günlük periyotlar halinde 
laktasyon döneminin sonuna kadar (3 ay) süt verim kontrollerine devam edilmiştir. Dolayısıyla sağım süresi, sağıma başlanan gün ile sağıma son verildiği tarih arasındaki gün sayısı olarak alınmış ve bu süre zarfinda elde edilen süt miktarı "toplam sağılan süt" olarak değerlendirilmiştir (Şekil 1). Toplam sağılan süt miktarı (TSSM), oğlağın emdiği hariç sağılan süt miktarını ifade etmektedir. TSSM'nın hesaplanmasında ICAR tarafindan belirtilen süt verim denetim yöntemi olan Yöntem 2 kullanılmıştır (Şekil 1).

Kontrol sağımlarında elde edilen süt miktarı, cam mezür ile ölçülmüş ve $\mathrm{ml}$ olarak kaydedilmiştir. Çalışmada süt verimleri belirlendikten sonra, her keçiye ait sütlerden süt kompozisyonunun belirlenmesi için örnekler alınmıştır. Süt örneklerinin alınmasında; kovadaki süt, yăg, protein vb. özelliklerin tayininde homojenizasyonu sağlamak için karıştırılmış, 50 ml'lik tüplere ikişer örnek alınmış, her hayvanın kulak numaraları tüpler üzerine yazılmış ve örnekleme işlemi tamamlanıncaya kadar sütler portatif buzdolabında muhafaza edilmiştir.

\section{Süt kompozisyonunun belirlenmesi}

Süt örneklerinde yağsız kuru madde, yağ, protein, $\mathrm{pH}$, laktoz ve iletkenliğin belirlenmesinde Milkana Multitest marka süt analiz cihazı kullanılmıştır.

\section{Meme ölçülerinin alınması}

Süt örneklerinin alındığı ilk gün (sağım başlangıc11.dönem) ve süt örneklerinin alındığı son gün (sağım sonu-6.dönem) olmak üzere iki kez hayvanların meme genişliği, meme çevresi, meme uzunluğu, meme başı uzunluğu ve genişliği, sarnıç derinliği, iki meme başı arası açı ve meme hacmi ölçümleri yapılmıştır (Şekil 2). Meme ölçüleri, sabah sağımından yaklaşık bir saat önce alınmıştır. Alınan meme ölçüleri (Kızılay, 1983):

A. Meme genişliği (MG): memenin en geniş orta yerinden,

B. Meme çevresi (MÇ): meme gövdesinin en geniş yerinden ve meme başlarının hemen üzerinden,
C. Meme uzunluğu (MU): memenin gövdeye bağlandığ 1 ön kısımdan gövdeye bağlandığı arka kısma kadar olan mesafe,

D. Sarnıç derinliği (SD): meme başının gövdeye bağlandığı alt kısım ile memenin yere en yakın kısmı arasindaki mesafe,

E. Meme başı uzunluğu (MBU): memenin gövdeye bağlandığı kısımdan meme başının ucuna kadar olan dikey mesafe,

F. Meme başı genişliği (MBG): meme başının en kalın yeri,

G. İki meme başı arası açısı (MBA): meme başları arasındaki mesafe,

H. Meme hacmi (MH): su taşırma metodu ile ölçülmüştür. Su ile doldurulmuş hacim ölçme kabına meme daldırılmış ve taşan suyun hacmi meme hacmi olarak kaydedilmiştir.

Meme çevresi, meme genişliği ve meme uzunluğunun ölçümü için ölçü şeridi; meme başı uzunluğu ve genişliği ile sarnıç derinliğinin ölçümü için kumpas; meme başları arasındaki mesafenin açı ölçümleri için de ölçü pergeli kullanılmıştır. Bu çalışma için Uludağ Üniversitesi Hayvan Deneyleri Yerel Etik Kurulu'ndan onay alınmıştır (2012-05/06).

\section{Verilerin değerlendirilmesi}

Elde edilen verilerin değerlendirilmesinde Minitab 16 paket programı kullanılmış, sağım başlangıcı ve sonundaki özellikler arasındaki farklılık paired t testi ile belirlenmiştir (Minitab, 2010).

\section{BULGULAR ve TARTIŞMA}

Toplam Sağılan Süt Miktarı, Meme Ölçüleri ve Arasındaki İlişkiler

Melez keçilerde TSSM, meme ölçülerine ait sağım başlangıcı ve sonu değerleri Çizelge 1'de verilmiştir.

Araştırmada Saanen x K1l F 1 melezi keçilerde, sağıma başlandığı 90. günden sağımın bittiği 180. güne kadar olan 90 günlük süre için TSSM $137.7 \mathrm{~kg}$ olarak tespit edilmiştir.

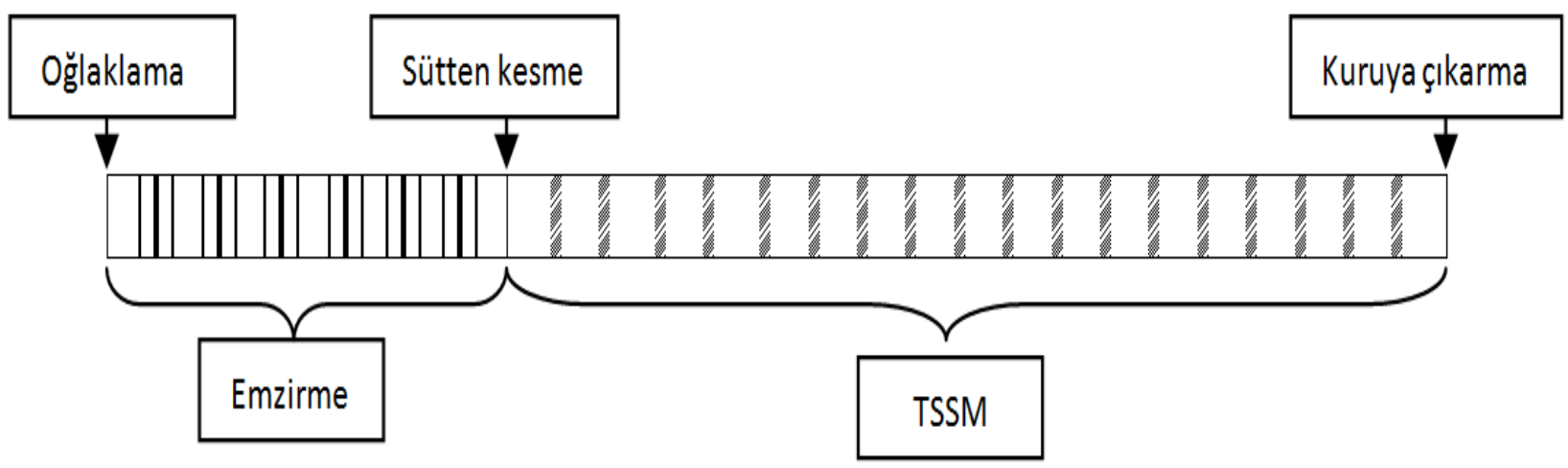

Şekil 1. Toplam sağılan süt miktarının belirlenmesi ICAR (2011) 


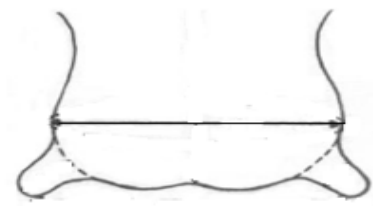

A.

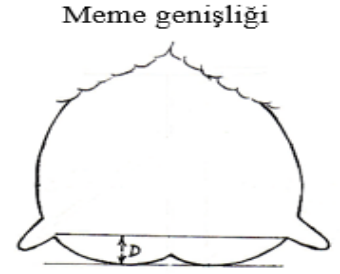

D. Sarnıç derinliği

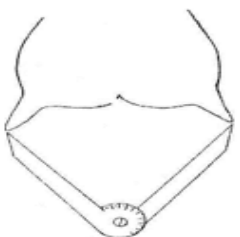

G. İki meme başı arası açı

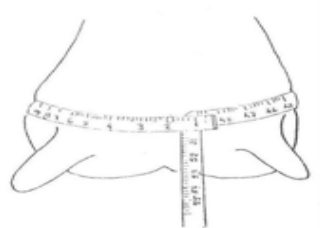

B. Meme çevresi

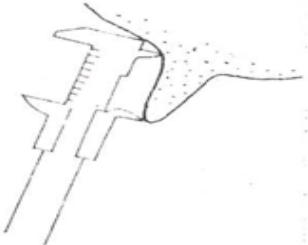

E. Meme başı uzunluğu

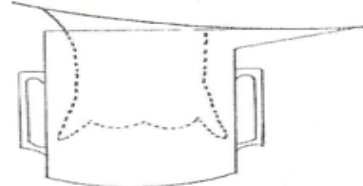

H. Meme hacmi

Şekil 2. Meme ölçüleri

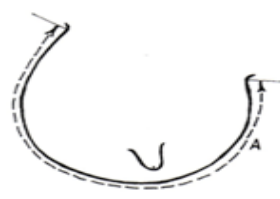

C. Meme uzunluğu

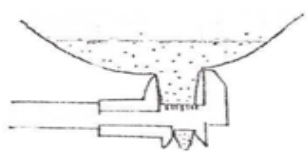

F. Meme başi genişliği

Çizelge 1. TSSM ve meme ölçülerine ait sağım başı ve sonu değerler

\begin{tabular}{|c|c|c|c|c|}
\hline TSSM (kg) & \multicolumn{2}{|c|}{$137.67 \pm 38.98$} & & \\
\hline Özellikler & Sağım başı & Sağım sonu & Önem düzeyi & T değeri \\
\hline Meme genişliği $(\mathrm{cm})$ & $28.47 \pm 5.39$ & $19.74 \pm 7.03$ & $* *$ & 14.26 \\
\hline Meme çevresi $(\mathrm{cm})$ & $53.03 \pm 6.85$ & $35.87 \pm 11.59$ & $* *$ & 16.81 \\
\hline Meme uzunluğu $(\mathrm{cm})$ & $35.68 \pm 6.82$ & $26.15 \pm 11.15$ & $* *$ & 10.55 \\
\hline Meme başı uzunluğu (mm) & $4.92 \pm 12.12$ & $3.76 \pm 11.03$ & $* *$ & 9.52 \\
\hline Meme başı genişliği (mm) & $3.21 \pm 8.89$ & $2.33 \pm 8.12$ & $* *$ & 7.62 \\
\hline Iki meme başı arası açı $\left(^{\circ}\right)$ & $17.87 \pm 3.10$ & $14.38 \pm 3.23$ & $* *$ & 10.31 \\
\hline Sarnıç derinliği (mm) & $1.03 \pm 0.60$ & $1.16 \pm 0.76$ & $* *$ & -3.07 \\
\hline Meme hacmi (l) & $1657.45 \pm 378.06$ & $398.81 \pm 184.27$ & $* *$ & 29.91 \\
\hline
\end{tabular}

$* * P<0.01$

Sönmez ve ark. (1970) Ege Bölgesi'nde yetiştirilen saf Saanenlerde laktasyon süt verimini 203.8 günlük laktasyon süresi için $286.9 \mathrm{~kg}$, Orman ve ark. (2011) Uludağ Üniversitesi'nde yetiştirilen Saanen rrk1 keçilerde 203.3 günlük laktasyon süresi için laktasyon süt verimini 309.2 kg, Tölü ve ark. (2010) Çanakkale'de yetiştirilen Saanenlerde 275 günlük laktasyon süresi için süt verimini $521.6 \mathrm{~kg}$, Aktaş ve ark. (2012) Kahramanmaraş'ta yetiştirilen Saanen keçilerinde 190.46 günlük laktasyon süresi için laktasyon süt verimini $237.65 \mathrm{~kg}$, Bolacalı ve ark. (2012) Muş'ta yetiştirilen Saanen keçilerinde 273.1 günlük laktasyon süresi için laktasyon süt verimini $383.05 \mathrm{~kg}$ olarak bildirmişlerdir.

Diğer yandan, Sönmez (1974) K1l keçilerinin 1. laktasyondaki süt verimini 158 günde $87.83 \mathrm{~kg}, 2$. laktasyondaki süt verimini 154 günde $107.34 \mathrm{~kg}$ olarak bildirmiştir. Ferik (1995) köy koşullarında yetiştirilen Kıl keçilerinin süt veriminin 169.5 gün için $100.6 \mathrm{~kg}$ olduğunu saptamıştır. Atay ve ark. (2010) tarafindan Kil keçilerinde laktasyon süresi ve laktasyon süt verimi sırasıyla 192.4 gün, $139.10 \mathrm{~kg}$ olarak belirtilmiştir. Erten ve Y1lmaz (2013) K1l keçilerinde laktasyon süresini 163.26 gün, laktasyon süt verimini $109.70 \mathrm{~kg}$ olarak tespit etmişlerdir. Sütten kesim ve buna bağlı olarak da sağım süresi rrklara ve işletmenin mevcut koşullarına göre değişiklik gösterebilmektedir. Elde edilen veriler incelenen literatür bildirişleri ile birlikte değerlendiğinde Kıl keçilerinin Saanen rrkı ile melezlenmesi sonucu süt veriminde belirgin bir iyileştirme sağlandığı ve yetiştirici şartlarında Saanen melezlerinden elde edilen verimlerin hemen hemen tatminkâr bir düzeyde olduğu sonucu çıkarılabilir.

Melez keçilerde meme çevresi için saptanan $44.5 \mathrm{~cm}$ değeri; Aktaş ve ark. (2012)'nın laktasyonun 4. ayında $34.46 \mathrm{~cm}$, Gendy ve ark. (2014)'nın laktasyonun 3. 
ayında $30.95 \mathrm{~cm}$, James ve ark. (2009)'nın $26.81 \mathrm{~cm}$, Abu ve ark. (2013)'nın bildirdiği $23.10 \mathrm{~cm}$ 'nin üstünde, Szymanowska ve ark. (2010)'nın laktasyonun 4. ayında bildirdiği 54.2 cm'nin altındadır. $\mathrm{Bu}$ farklılıklar kullanılan ırkların yanı sıra ölçümlerin yapıldığı dönemin farklı olmasından kaynaklanmaktadır. Meme başı uzunluğunun, laktasyon sonuna doğru memelerin küçülerek vücuda çekilmesi ile kısaldığı, sarnıç derinliğinin ise laktasyonun sonuna doğru memedeki gerginliğin azalması ile arttığı görülmüştür. Fernandez ve ark. (1995) iyi ve sağlıklı olarak değerlendirilen memenin büyük ve hacimli, meme başlarının orta uzunluk ve genişlikte olması ve yere dik uzanması gerektiğini ifade etmektedir. Meme hacmindeki azalma, araştırmada laktasyon sonuna doğru süt veriminin düşmeye başlamasıyla birlikte memelerin küçülmesi ve hayvanın vücuduna doğru çekilmesinden kaynaklanmaktadır. Kor ve ark. (2004) da meme başları arasındaki açının makineli sağımda önemli bir özellik olduğunu ve meme başları yatay duruşa ne kadar yakın olursa sağımın o ölçüde güçleştiğini belirtmişlerdir. İki meme başı arası açı, laktasyon sırasının artmasıyla birlikte artmakta ve sağım periyodunun sonunda azalmaktadır (Peris ve ark., 1999). Melez keçilerde de iki meme başı arası açı, sütün azalıp memenin gevşemesine bağlı olarak laktasyon sonuna doğru azalmıştır.

Birçok çalışmada meme özellikleri içinde özellikle meme başı yerleşiminin, süt verimi ve sağım kolaylığ noktasında belirleyici olduğu ifade edilmektedir (De la Fuente ve ark., 1999; Akpa ve ark., 2002). Meme özellikleri genotip, yetiştirme ve yönetim sistemi gibi çeşitli faktörlerden etkilenmektedir (Milerski ve ark. 2006). Bu çalışmada, sağım başlangıcı döneminde elde edilen süt miktarı ile MG, MÇ, MU ve İMBA değerleri arasındaki, sağım sonunda elde edilen süt miktarı ile MG, MÇ ve MU değerleri arasındaki korelasyonların önemli olduğu belirlenmiştir (Çizelge 2, 3). Fernandez ve ark. (1995) süt verimi üzerinde en etkili faktörün MÇ olduğunu, meme özelliklerinden MY ve MG arasındaki korelasyonun da yüksek ve pozitif olduğunu ifade etmiştir. Kaya (2005), Akkeçilerde süt verimi ile MÇ ve İMBA arasında sırasıyla 0.672, 0.595 düzeyinde bir ilişki bulunduğunu bildirmiştir $(\mathrm{P}<0.01)$. Akporhuarko (2015), meme ve meme başı özellikleri arasında yüksek düzeyde pozitif fenotipik korelasyon bulunduğunu belirtmiştir. Kızılay (1983) tarafından MG ve MÇ ile süt verimi arasında yüksek düzeyde pozitif korelasyon bulunduğu, meme başlarına ait fenotipik özellikler söz konusu olduğunda ise korelasyonların negatif ve düşük düzeylerde kaldığı bildirilmiştir. Wang (1989), Togenburg keçilerinde çoğu meme özelliği ile 180 günlük süt verimi arasında yüksek düzeyde korelasyon bulunduğunu saptamıştır. Montalto ve Martinez-Lozano (1993), yürüttüğü çalışmada MÇ ile süt verimi arasındaki korelasyonun $0.81(\mathrm{P}<0.01)$ düzeyinde olduğunu tespit etmiştir. Kor ve ark. (2004) MG ile birlikte, süt veriminin hem laktasyon sırası ve hem de yaşa göre farklılık $(\mathrm{P}<0.05)$ gösterdiğini, Iniguez ve ark. (2009) da süt verimi ile meme ve meme başı özellikleri arasında pozitif korelasyon bulunduğunu belirtmiştir. Gendy ve ark. (2014), Damascus ve Zaraibi keçilerinde süt veriminin artışıyla orantılı olarak MU'nun da arttığını bildirmişlerdir.

Merkhan (2014) meme özelliklerinden MÇ’nin süt veriminin en iyi belirteçleri olduğunu ve süt verimi bakımından uygulanacak bir seleksiyonda mutlaka göz önünde bulundurulması gerektiğini ifade etmiştir. Fernandez ve ark. (1995) da çalışmalarında süt verimi üzerinde en etkili faktörün MÇ olduğunu saptamışlardır. $\mathrm{Bu}$ çalışmada elde edilen bulgular, incelenen literatür çalışmalarını desteklemektedir.

Çizelge 2. Sağım başlangıcı meme ölçüleri ve TSSM arasındaki korelasyon katsayıları

\begin{tabular}{|c|c|c|c|c|c|c|c|c|}
\hline Özellikler & MG & MÇ & SD & MU & MBU & MBG & IMBA & MH \\
\hline MÇ & $\mathbf{0 . 8 6 5}^{* *}$ & & & & & & & \\
\hline SD & 0.203 & 0.183 & & & & & & \\
\hline MU & $\mathbf{0 . 7 3 9}^{* *}$ & $\mathbf{0 . 7 6 9}^{* *}$ & 0.121 & & & & & \\
\hline MBU & -0.065 & 0.037 & -0.111 & -0.207 & & & & \\
\hline MBG & 0.140 & 0.172 & 0.014 & -0.025 & $\mathbf{0 . 7 2 1}^{* *}$ & & & \\
\hline İMB & $\mathbf{0 . 3 7 4}^{*}$ & $\mathbf{0 . 5 2 3}^{* *}$ & 0.037 & $\mathbf{0 . 4 8 1}^{* *}$ & 0.170 & 0.155 & & \\
\hline MH & 0.184 & 0.234 & 0.106 & $\mathbf{0 . 2 9 5}^{* *}$ & -0.101 & -0.099 & 0.053 & \\
\hline TSSM & $\mathbf{0 . 5 8 0}^{* *}$ & $\mathbf{0 . 7 7 6}^{* *}$ & 0.070 & $\mathbf{0 . 6 0 5}^{* *}$ & 0.121 & 0.236 & $\mathbf{0 . 5 4 2}^{* *}$ & 0.050 \\
\hline
\end{tabular}

$* P<0.05, * * P<0.01$

Çizelge 3. Sağım sonu meme ölçüleri ve TSSM arasındaki korelasyon katsayıları

\begin{tabular}{|c|c|c|c|c|c|c|c|c|}
\hline Özellikler & MG & MÇ & SD & MU & MBU & MBG & IMBA & MH \\
\hline MÇ & $\mathbf{0 . 8 7 4}^{* *}$ & & & & & & & \\
\hline SD & 0.053 & 0.027 & & & & & & \\
\hline MU & $\mathbf{0 . 9 0 4}^{* *}$ & $\mathbf{0 . 8 6 2}^{* *}$ & 0.056 & & & & & \\
\hline MBU & $\mathbf{- 0 . 2 9 3}^{*}$ & -0.150 & -0.040 & -0.260 & & & & \\
\hline MBG & 0.047 & 0.129 & 0.019 & 0.107 & $\mathbf{0 . 7 4 0}^{* *}$ & & & \\
\hline IMBA & $\mathbf{0 . 4 4 6}^{* *}$ & $\mathbf{0 . 4 2 6}^{* *}$ & $0.293^{*}$ & $\mathbf{0 . 4 0 3}^{*}$ & 0.032 & 0.062 & & \\
\hline MH & $\mathbf{0 . 4 1 8}^{*}$ & $\mathbf{0 . 3 2 7}^{*}$ & 0.043 & $\mathbf{0 . 5 0 3}^{* *}$ & -0.264 & -0.077 & 0.081 & \\
\hline TSSM & $\mathbf{0 . 3 6 7}^{*}$ & $\mathbf{0 . 3 4 8}^{*}$ & -0.171 & $\mathbf{0 . 4 1 9}^{* *}$ & -0.083 & 0.076 & 0.170 & 0.049 \\
\hline
\end{tabular}




\section{Süt Kompozisyonu, Toplam Sağılan Süt Miktart ve Arasındaki İlişkiler}

Saanen x K1l F1 melezi keçilerden elde edilen sütün kompozisyon özelliklerine ait değerler Çizelge 4'de verilmiştir. Süt örneklerinde yağsız KM oranı \% $7.79-\%$ 11.3 arasında olup, ortalama \% 9.70 bulunmuştur. $\mathrm{Bu}$ değer, Çiğ Süt ve Isıl İşlem Görmüş İçme Sütleri Tebliği'nde (Tebliğ No:2000/6) bildirilen en az \% 8.5 olmalı şartını sağlamaktadır (Anonim, 2000).

Çizelge 4. Sütün kimyasal bileşimine ait tanımlayıcı değerler

\begin{tabular}{|c|c|c|c|c|c|}
\hline Özellikler & $\mathbf{N}$ & $\overline{\mathrm{X}}$ & $\mathrm{S}_{\overline{\mathrm{X}}}$ & Min. & Max. \\
\hline Yağ (\%) & 47 & 3.15 & 0.26 & 1.15 & 7.75 \\
\hline Protein (\%) & 47 & 4.24 & 1.07 & 2.87 & 5.87 \\
\hline $\mathrm{pH}$ & 47 & 6.20 & 0.01 & 6.19 & 6.27 \\
\hline Laktoz (\%) & 47 & 4.37 & 0.18 & 4.02 & 4.66 \\
\hline $\begin{array}{c}\text { Iletkenlik } \\
\text { (mS/cm) }\end{array}$ & 47 & 5.33 & 0.40 & 4.16 & 6.14 \\
\hline Yağsız KM (\%) & 47 & 9.70 & 1.55 & 7.79 & 11.3 \\
\hline
\end{tabular}

Yağsız KM oranı bakımından bulunan değerler; Kesenkaş ve ark. (2010)'nın Saanen keçi irkından elde edilen sütlerde bulduğu \% 14.99 değerinin altında, Ahamefule ve ark. (2012)'nın Red Skoto ve Afrika cüce keçi sütlerindeki $\% 8.22$ ve $\% 8.59$, Bhosale ve ark. (2009)'nın Hindistan'daki yerli keçi ırklarından elde edilen sütlerde 1 . ve 3 . laktasyonda bulduğu \% 8.76 ve \% 9.05 değerlerinin üstünde bulunmuştur. Bu farklılıkların yetiştiricinin hayvanlara sağladığı bakım-besleme şartları, genetik yapı ve uygulanan analiz yönteminden kaynaklanmış olabileceği düşünülmektedir.

Sütün yağ içeriği; esansiyel yağ asitleri, yağda eriyen vitaminler ve enerji için önemli bir kaynaktır. Süt örneklerinde yağ oranı ortalama \% 3.15 olarak bulunmuştur. Ortalama süt yağı oran1, genelde çalışmalarda bildirilen sınırlar içerisinde yer almakla birlikte gida kodeksinde yer alan en az \% 4.15 olmalı şartını sağlamamaktadır (Anonim, 2000). Kuchtik ve ark. (2015) Kıl keçilerinde laktasyonun 90. gününde yağ oranını \% 3.29 olarak bildirmişlerdir. Bununla birlikte araştırmada tespit edilen değer, Katanos ve ark. (2005)'nın süt yağı oranının hem ırk hem de laktasyon aşamalarına göre değişiklik gösterdiği ve melez süt keçilerinde süt yağı oranının orta düzeyde olduğu ifadesini desteklemektedir. Ancak süt kuru maddesinde önemli bir yer tutan süt yağı oranı için bu çalışmada elde edilen değer, yetiştiricinin yetiştirme ve besleme koşulları da dikkate alındığında hiç de azımsanmayacak bir düzeydedir. Özellikle kaba yem kalitesi, kaba yem/kesif yem oranı, yemleme sıklı̆̆ vb. bazı besleme uygulamaları daha dikkatli takip edildiğinde gözlenen bu varyasyonun daha azalacağı tahmin edilmektedir. Araştırmada süt örneklerinin protein içeriğinin \% 2.87 ile \% 5.87 arasında değiştiği görülmektedir. Çiğ Süt ve Isıl İşlem Görmüş İçme Sütleri Tebliği'ndeki (Tebliğ No:2000/6) protein oranının en az \% 2.80 olmas1 gerekliliğini karşılamaktadır (Anonim, 2000). Kuchtik ve ark. (2015) Kıl keçilerinde laktasyonun 90. gününde protein düzeyinin \% 2.69 olduğunu ve laktasyonun sonuna doğru \% 2.06 düzeyine gerilediğini bildirmişlerdir. Mayer ve Fiechter (2013) keçi sütlerinde protein miktarının Mart-Ağustos ayları arasında \% 2.71 ve \% 4.90 olarak değişiklik gösterdiğini ve özellikle peynire işlenecek sütlerde mevsimin dikkate alınması gerektiğini ifade etmişlerdir. Katanos ve ark. (2005) keçilerde süt protein oranının laktasyon aşamalarından etkilenmekle birlikte süt yağı oranına göre çok daha stabil olduğunu belirtmişlerdir.

Sütte $\mathrm{pH}$ değeri sütün asitliğini ifade etmektedir ve sütün stabilitesi üzerine etki eden en önemli faktörlerden biridir. Sütün pH'sı, normal kabul edilen değerlerden sapma gösterdiğinde hem süt hem de süt ürünleri kalitesi olumsuz etkilenmektedir (Ceylan ve ark. 2013). Schultz ve Chandler (1921) taze keçi sütlerinde $\mathrm{pH}$ değerinin 6.4 - 6.7 arasında değiştiğini, Mahmood ve Usman (2010) 6.48 - 6.64 arasında bir değer aldığını, Sabahelkhier ve ark. (2012) ve Hassan (2013) ise bu değeri 6.60 olarak bildirmişlerdir. Araştırmada incelenen süt örneklerinde pH değeri ortalama 6.20 olarak bulunmuştur. Nispeten düşük olan bu $\mathrm{pH}$ değeri, süt alımından analiz yapılıncaya kadar geçen sürede sütte muhtemel mikroorganizma üremesinden kaynaklanmış olabilir (Creager ve ark., 1990).

Laktoz, doğada sadece sütte bulunmakta ve hem süt ürünlerinin üretilmesinde hem de insan beslenmesinde önemli bir yer tutmaktadır. Laktoz, keçi sütünün en önemli karbonhidratıdır. Keçi sütü bağırsaklarda daha kolay ve tamamen sindirilebildiğinden laktoz intoleransı bulunan kişiler tarafindan da rahatlıkla tüketilebilmektedir. Laktoz miktarı mevsim, laktasyon dönemi gibi faktörlere bağlı olarak değişiklik göstermektedir (Baştan ve ark., 1997). Süt örneklerinde saptanan ortalama \% 4.37 laktoz değeri, Ahamefule ve ark. (2003; 2012), Bhosale ve ark. (2009) ve Ibnelbachyr ve ark. (2015), Katanos ve ark. (2005), Kuchtik ve ark. (2015)'nın bildirdiği değerlerden düşük, Mayer ve Fiechter (2013)'in bulduğuna benzer, Kesenkaş ve ark. (2010) ile Strzalkowska ve ark. (2009)'nın saptadığ değerlerden yüksektir.

Sütün iletkenliğinin, önemli bir kısmı sodyum (Na), klor $(\mathrm{Cl})$ ve potasyum $(\mathrm{K})$ iyonlarından kaynaklanır. Süt yağının artması ve süte su katılması elektriksel iletkenliği düşürmektedir. Diğer yandan mastitisli meme dokusunda damar geçirgenliğinin artmasına bağlı olarak sütün iyonik bileşimi de değişmekte ve bu değișimler sonucu sütün elektriksel iletkenliği yükselmektedir. Meme dokusunda meydana gelen hasar sonucu sütün asitliği, laktoz ve $\mathrm{K}+$ konsantrasyonu azalmakta buna karşın $\mathrm{Na}+$ ve Cl- iyonu konsantrasyonları artmaktadır (Aytekin ve Boztepe, 2014). Böylece sütün peynir ve yoğurt mayası ile pıhtılaşması güçleşmekte ve randımanı azalmaktadır. Elektriksel iletkenlik değerlerindeki $1 \mathrm{~ms} \mathrm{~cm}^{-1}$ artış, süt veriminde $0.88 \mathrm{~kg} /$ gün düzeyinde azalmaya yol açmaktadır (Nielen ve ark., 1992). Araştırmadaki süt örneklerinde elektriksel iletkenlik değeri ortalama 5.33 $\mathrm{ms} \mathrm{cm} \mathrm{cm}^{-1}$ olarak bulunmuştur. Roukbi ve ark. (2015) sağlıklı keçilere ait sütlerde elektriksel iletkenlik değerlerinin 3.93-4.47 ms cm${ }^{-1}$ arasında olduğunu, bu 
değerin üzerine çıkıldığında meme bezlerinde patolojik oluşumların meydana gelme riskinin artacağını ifade etmektedirler. Diğer yandan Nielen ve ark. (1992) elektriksel iletkenliğin normal sütte $4-5.5 \mathrm{~ms} \mathrm{~cm}^{-1}$ arasında değiştiğini, $5.6 \mathrm{~ms} \mathrm{~cm}^{-1}$ 'nin üzerindeki değerlerde mastitisten şüphe edilmesi gerektiğini bildirmektedir.

Sütün yağ, protein ve toplam KM oranları üzerinde besleme (Wang, 1989) ve laktasyon dönemi (Şengonca ve ark., 2003) önemli etkiye sahiptir. Ayrıca sütün protein ve yağ oranı yaz aylarında, kış aylarına oranla düşmektedir. $\mathrm{Bu}$ nedenle süt kompozisyonu bakımından yapılan çalışmalarda miktar bakımından farklı sonuçlar elde edilmesi beklenen bir durumdur. Ancak özelliklerin birbirleriyle ve süt verimiyle olan ilişkilerinin hangi yönde ve ne düzeyde olduğunun belirlenmesi büyük öneme sahiptir.

Süt kompozisyonu ile TSSM arasındaki fenotipik korelasyon katsayıları Çizelge 5'de verilmiştir.

Petrovic ve ark. (2005) süt miktarı ile yăg oranı arasındaki korelasyonun $0.30-0.40$, süt verimi ile protein oranı arasındaki korelasyonun $0.40-0.50$ düzeyinde olduğunu ifade etmiştir. Bu çalışmada protein oranı ile TSSM arasındaki korelasyon Petrovic ve ark. (2005)'nın bildirdiği gibi pozitif yönde ve önemli bulunurken, tersine süt verimi ile yağ oranı arasındaki korelasyon oldukça düşük ve önemsiz bulunmuştur. Bunun keçilerin melez genotipli olmalarından kaynaklanabileceği düşünülmektedir. Irklara göre protein oranının ve türünün değişiklik gösterdiği bilinmektedir (Linn, 1988).

Çizelge 5. Süt kompozisyonu ile TSSM arasındaki fenotipik korelasyon katsayıları

\begin{tabular}{|l|c|c|c|c|c|c|}
\hline Özellikler & TSSM & Yă & Protein & pH & Laktoz & Iletkenlik \\
\hline Yăg & 0.069 & & & & & \\
\hline Protein & $\mathbf{0 . 2 9 3}^{*}$ & 0.207 & & & & \\
\hline $\mathrm{pH}$ & -0.173 & -0.083 & $\mathbf{- 0 . 3 5 8 *}^{*}$ & & & \\
\hline Laktoz & 0.129 & 0.101 & $\mathbf{0 . 3 9 4}^{* *}$ & -0.043 & & \\
\hline Iletkenlik & 0.110 & 0.208 & -0.014 & -0.095 & 0.164 & \\
\hline Yağsiz KM & 0.168 & 0.181 & $\mathbf{0 . 6 4 8}^{* * *}$ & -0.388 & 0.271 & 0.101 \\
\hline
\end{tabular}

$* P<0.05 * * P<0.01$

Araştırmada sütün protein oranı ile $\mathrm{pH}$ değeri arasında negatif $(\mathrm{P}<0.05)$, laktoz ve yağsız $\mathrm{KM}$ ile arasında pozitif bir ilişki $(0.69)$ tespit edilmiştir $(\mathrm{P}<0.01)$. Özellikle protein oranındaki değişiklikler sütün pıhtılaşma özelliğini değiştirmektedir. Pıhtılaşma özellikleri sütün peynire işlenmesinde çok önemlidir (Ariota ve ark., 2007). Süt kompozisyonundaki olumsuz değişiklikler sütün ve dolayısıyla bu sütten işlenerek elde edilecek ürünlerin de kalitesini düşürmektedir. $\mathrm{Bu}$ araştırmada $\mathrm{pH}$ değeri ile protein ve yağ oranı arasında tespit edilen ilişkiler Piiroonen ve ark. (1992) ile Ariota ve ark. (2007)'nın bildirişlerini desteklemektedir.

\section{SONUÇ}

Bu çalışmada, ekstansif koşullarda yetiştirilen Saanen $\mathrm{x}$ Kıl melezlerinin süt verim özellikleri ve süt kompozisyonu belirlenmeye çalışılmıştır. Saanen x Kıl keçi $F_{1}$ genotinin süt verimi açısından $K_{1} l$ keçilerinden daha iyi durumda olduğu saptanmıştır. Diğer taraftan incelenen keçi sütü bileşenlerinin çeşitli parametreler bakımından ağırlıklı olarak gıda kodeksindeki değerlere uygun olduğu gözlenmiştir. Ayrıca laktasyonun ortasından itibaren sağıma başlanıp son 90 günlük verim alınmasına rağmen azımsanmayacak miktarda pazarlanabilir süt elde edilebilmiştir. Bu noktada keçi sütü üretimini artırmada saf ırkların yanında çok eskiden beri uygulanan doğru melezleme uygulamaları ile süt veriminde planlı bir artış sağlanırken beraberinde yetiştirme koşullarında uygulamaya alınacak sağım sistemleri ile kaliteli süt üretme noktasında Türkiye'nin önemli firsatlara sahip olduğu görülmüştür. Türkiye'nin farklı illerinde uygulanan süt verimini artırmaya yönelik melezleme çalışmaları, doğru yapılacak seleksiyon ve bakım-besleme koşullarının iyileştirilmesi ile daha iyi sonuçlara ulaşılması kaçınılmazdır. Bununla birlikte sütteki kompozisyon değişikliklerinin takip edilmesi gerek halk sağlığının korunması ve gerek oluşacak ekonomik kayıpların önlenmesi noktasında büyük öneme sahiptir.

\section{TEŞEKKÜR}

$\mathrm{Bu}$ çalışma Uludağ Üniversitesi Bilimsel Araştırmalar Proje Birimi (2011/60) tarafindan desteklenen projenin bir bölümünü içermektedir. Çalışmanın yürütülmesinde maddi destek sağlayan Bilimsel Araştırmalar Proje Birimi'ne teşekkür ederiz.

\section{KAYNAKLAR}

Abu AH, Mhomga LI, Akogwu EI 2013. Assessment of Udder Characteristics of West African Dwarf (WAD) Goats Reared Under Different Management Systems in Makurdi, Benue State, Nigeria. African Journal of Agricultural Research, 8(25): 3255-3258.

Ahamefule FO, Ibeawuchi JA, Ejiofor CA 2003. A Comparative Study of The Constituents of Cattle, Sheep and Goat Milk in a Hot Humid Environment. Discovery and Innovation, 15(1/2): 64-68.

Ahamefule FO, Odilinye O, Nwachukwu EN 2012. Milk Yield and Composition of Red Sokoto and Weast African Dwarf Does Raised Intensively in a Hot Humid Environment. Iranian Journal of Applied Animal Science, 2(2): 143-149.

Akpa GN, Asiribo OE, Oni OO, Alawa JP, Dim NI, Osinowo OA, Abubakar BY 2002. Milk Production 
by Agro Pastoral Red Sokoto Goats in Nigeria. Tropical Animal Health Production, 34: 525-533.

Akporhuarho PO 2015. Assessment of Udder Size and Milk Yield of West African Dwarf (WAD) Goats Reared Under Semi Intensive Management System in Humid Nigeria. Global Journal of Animal Scientific Research, 3(1): 36-40.

Aktaş ZM, Kaygısız A, Baş S 2012. Kahramanmaraş yetiştirici şartlarında Türk Saanen Keçilerinin süt verim özellikleri, bazı meme ölçüleri ve SHS arasındaki ilişkiler. Kahramanmaraş Sütçü İmam Üniversitesi Doğa Bilimleri Dergisi, 15(4):7-17.

Anonim 2000. Türk Gıda Kodeksi. Çiğ Süt ve Isıl İşlem Görmüş İçme Sütleri Tebliği (Tebliğ No: 2000/6). Resmi Gazete, 14 Şubat 2000 - Sayı: 23964. (Erişim tarihi: 04.01.2016).

Ariota B, Campanile G, Potena A, Napolano R, Gasparrini B, Neglia GL, DiPalo R 2007. Ca and P in Buffalo Milk: Curd Yield and Milk Clotting Parameters. Italian Journal of Animal Science, 6(6): 497-499.

Atay O, Gökdal Ö, Eren V 2010. Yetiştirici Koşullarında K1l Keçilerin Kimi Verim Özellikleri. Ulusal Keçicilik Kongresi 2010,24-26 Haziran 2010, Çanakkale Onsekiz Mart Üniversitesi, Çanakkale, 207-210.

Aytekin İ, Boztepe S 2014. Süt Sığırlarında Somatik Hücre Sayısı, Önemi ve Etki Eden Faktörler. Türk Tarım-Gıda Bilim ve Teknoloji Dergisi, 2(3): 112 121.

Baştan A, Fındık M, Kaymaz M, Duru Ö 1997. İnek Sütlerinde Somatik Hücre Sayısı, Serum Proteinleri, Laktoz Ve Elektriksel iletkenlik arasındaki ilişkinin araştırılması. Ankara Üniversitesi Veteriner Fakültesi Dergisi, 44: 63-67.

Bhosale SS, Kahate PA, Kamble K, Thakare VM, Gubbawar SG 2009. Effect of Lactation on PhysicoChemical Properties of Local Goat Milk. Veterinary World, 2(1): 17-19.

Bolacalı M, Küçük M 2012. Muş Bölgesinde Yetiştirilen Saanen Keçilerinin Döl Verimi ve Süt Verimi Özellikleri. Kafkas Üniversitesi Veteriner Fakültesi Dergisi, 18(3): 351-358.

Ceylan B, Çimen M, Bakır K, Oduncu İ 2013. Farklı Mevsimlerden Elde Edilen İnek Sütlerinde $\mathrm{pH}$ Seviyelerinin Peynir Standartlarına Uygunluklarının Belirlenmesi. Bilim ve Gençlik Dergisi, 1(1): 7-12.

Creager JG, Black JG, Davision VE 1990. Microbiolojy principles and applications. Prentice Hall, Inc; Englewood Cliffs, New Jersey, 722s.

De la Fuente LF, Fernandez G, San Primitivo F 1999. A Linear Evaluation System for Udder Traits of Dairy Ewes. Livestock Production Science, 45: 171-178.

Erten Ö, Yılmaz O 2013. Ekstansif Koşullarda Yetiştirilen Kıl Keçilerinin Döl ve Süt Verimi Özelliklerinin Araștırılması, YYÜ Veteriner Fakültesi Dergisi, 24: 105-107.

Ferik A 1995. Köy Koşullarında Yetiştirilen K1l Keçilerinde Süt, Döl ve Kıl Verileriyle İlgili Bazı Özelliklerin Saptanması Üzerine Bir Araştırma.
Yüksek Lisans Tezi. Uludağ Üniversitesi Fen Bilimleri Enstitüsü Zootekni Anabilim Dalı, Bursa.

Fernandez G, Alvarez P, San Primitivo F, De la Fuente LF 1995. Factors Affecting Variation of Udder Traits of Dairy Ewes. Journal of Dairy Science, 78: 842849.

Gendy ME, Hafsa FH, Youssef EOH, Saifelnasr ElSanafawy HA, Saba FE 2014. Relationship Between Udder Characteristics and Each of Reproductive Performance and Milk Production and Milk Composition in Zaraibi and Damascus Dairy Goats. Egyptian Journal Sheep Goat Science, 9(3): 95-104.

Hassan HJ 2013. Variations in Milk Composition of Some Farm Animals Resulted by Sub-Clinical Mastitis in Al-Diwania Province. Basrah Journal of Veterinary Research, 12(2): 17-24.

Ibnelbachyr M, Boujenane I, Chikhi A, Noutfia Y 2015. Effect of Some Non-Genetic Factors on Milk Yield and Composition of Draa Indigenous Goats Under an Intensive System of Three Kiddings in 2 years. Tropical Animal Health Production, 47: 727-733.

ICAR 2011. International Committee for Animal Recording. Rules, Standards and Guidelines for Milk Recording in Goats. http://www.icar.org. (Erişim tarihi: 04.01.2016).

Iniguez ZL, Hilali M, Tomas DL, Jesry G 2009. Udder Measurements and Milk Production in Two Awassi Sheep Gerotypes and Their Crosses. Journal of Dairy Science, 92: 4613-4620.

James IJ, Osinowo OA, Adegbasa OI 2009. Evaluation of Udder Traits of West African Dwarf (WAD) Goats and Sheep in Ogun State, Nigeria. Journal of Agricultural Science and Environment, 9(1): 75-87.

Katanos J, Skapetas B, Laga V 2005. Machine Milking Ability and Milk Composition of Some İmported Dairy Goat Breeds and Some Crosses in Greece. Czech Journal Animal Science, 50: 394-401.

Kaya SÖ 2005. Akkeçilerde Somatik Hücre Sayılarının Saptanması, Bazı Verim ve Meme Özellikleri ile İlişkileri. Ankara Üniversitesi Fen Bilimleri Enstitüsü, Zootekni Anabilim Dalı, Ankara.

Kesenkaş H, Dinkçi N, Kınık Ö, Gönç S, Ender G 2010. Saanen keçisi sütünün genel özellikleri. Akademik Gida, 8(2): 45-48.

Kızılay E 1983. Beyaz Alman x Malta $\left(\mathrm{F}_{1}\right)$ Keçilerinde Meme Özellikleri ve Süt Verimleriyle İlişkileri. Ege Üniversitesi Ziraat Fakültesi Yayınları, No: 461.

Kor A, Keskin S, Karaca S, Arslan S 2004. Akkeçilerde Yaş ve Laktasyon Sırasının Bazı Meme Özelliklerine Etkisi. YYÜ Ziraat Fakültesi Tarım Bilimleri Dergisi, 14(2): 105-111.

Kuchtík J, Králíčková1 S, Zapletal D, Węglarzy K, Šustová K, Skrzyżala I 2015. Changes in PhysicoChemical Characteristics, Somatic Cell Count and Fatty Acid Profile of Brown Short-Haired Goat Milk During Lactation. Animal Science Papers and Reports 33(1): 71-83.

Labussière J, Dotchewski D, Combaut JF 1981. Caractéristiques Morphologiques de la Mamelle des Brebis Lacaune. Méthodologie Pour l'obtention Des 
Données. Relations avec l'aptitude à la traite. Annales de Zootechnie, 30: 115-136.

Linn JG 1988. Factors Affecting the Composition of Milk from Dairy Cows. Committee on Technological Options to Improve the Nutritional Attributes of Animal Products, National Research Council,University of Minnesota, 224-241.

Mahmood A, Usman S 2010. A Comparative Study on The Physicochemical Parameters of Milk Samples Collected From Buffalo, Cow, Goat and Sheep of Gujrat, Pakistan. Pakistan Journal of Nutrition, 9(12): 1192-1197.

Mayer HK, Fiechter G 2013. Physicochemical Characteristics of Goat's Milk in Austria-Seasonal Variations and Differences Between Six Breeds. Dairy Science and Technology, 92: 167-177.

Merkhan KY 2014. Milk Traits and Their Relationship with Udder Measurements in Awassi Ewes. Iranian Journal of Applied Animal Science, 4(3): 521-526.

Milerski M, Margetin M, Čapistrak A, Apolen D, Španik J, Oravcova M 2006. Relationships Between External and Internal Udder Measurements and The Linear Scores for Udder Morphology Traits in Dairy Sheep. Czech Journal of Animal Science, 51: 383-390.

Minitab 2010. Minitab for Windows. Version 16 Minitab.Inc.,United States.

Montalto H, Martinez-Lozano FJ 1993. Phenotypic Relationships Between Udder and Milking Characteristics, Milk Production and California Mastitis Test İn Goat. Small Ruminant Research, 12(3): 329-337.

Nielen M, Deluyker H, Schukken Y, Brand A 1992. Electrical Conductivity of Milk: Measurement, Modifiers and Meta Analysis of Mastitis Detection Performance. Journal of Dairy Science, 75: 606-614.

Orman A, Günay A, Balcı F, Koyuncu M 2011. Monitoring of Somatic Cell Count Variations during Lactation in Primiparous and Multiparous Turkish Saanen Goats (Capra Hircus). Turkish Journal of Veterinay Animal Science, 33: 169-175.

Peris S, Caja G, Such X 1999. Relationship between udder and milking traits in Murciano-Granadina dairy goats. Small Ruminant Research, 12(3): 171-179.

Petrovic MP, Mekic C, Ruzic D, Zujovic M 2005. Genetic Principles Relating to Improvement of Milk Yield in Sheep and Goats. Biotechnology in Animal Husbandry, 21(5-6): 73-78.

Piironeen T, Ojala M, Niini T, Syvaoja EL, Setala J 1992. Effects of Milk Protein Genetic Variants and Lactation Stage on Renneting Properties of Bovine Milk. 43rd EAAP Meeting, 14-17 September 1992, Madrid, s. 1-12.

Roukbi M, Omar AN, Salam Z, Dibeh K 2015. Investigation of Subclinical Mastitis Cases in
GCSAR Damascus Goats from Humeimeh Research Station. Net Journal of Agricultural Science, 3(1): 513.

Sabahelkhier MK, Faten MM, Omer FI 2012. Comparative Determination of Biochemical Constituents Between Animals (goat, sheep, cow and camel) Milk with Human Milk. Research Journal of Recent Sciences, 1(5): 69-71.

Schultz EW, Chandler LR 1921. The Acidity of Goat's Milk in Terms of Hydrogen Ion Concentration, With Comparisons to That of Cow's And Human Milk. The Journal of Biological Chemistry, 46: 129-132.

Sönmez R, Şengonca M, Alpbaz AG 1970. Ege Üniversitesi Ziraat Fakültesinde Yetiştirilen Saanen Süt Kecilerinin Çeşitli Özellikleri ve Verimleri Üzerine Bir Araştırma. Ege Üniversitesi Ziraat Fakültesi Dergisi, 7(1): 35-46.

Sönmez R 1974. Melezleme Yolu ile Yerli K1l Keçilerinin Süt Keçilerine Çevrilme Olanakları. Ege Üniversitesi, Ziraat Fakültesi Yayınları, No: 226, Bornova, İzmir.

Strzalkowska N, Jóźwik A, Bagnicka E, Krzyżewski J, Horbańczuk K, Pyzel B, Olav J 2009. Chemical Composition, Physical Traits and Fatty Acid Profile of Goat Milk as Related to The Stage of Lactation. Animal Science Papers and Reports, 27(4): 311-320.

Szymanowska A, Patkowski K, Miduch A, Milerski M 2010. Correlation Between Mammary Gland Morphology and Gland Cistern Size to Lactation Milk Yield in Goat. Zootech, (28)4: 36-43.

Şengonca M, Taşkın T, Koşum N 2003. Saanen x Kıl Keçi Melezlerinin ve Saf Kıl Keçilerinin Kimi Verim Özelliklerinin Belirlenmesi Üzerine Eş Zamanlı Bir Araștırma. Turkish Journal of Veterinary and Animal Science, 27: 1319-1325.

Şimşek ÜG, Bayraktar M, Gürses M 2006. Çiftlik Koşullarında Kıl Keçilerine Ait Bazı Verim Özelliklerinin Araştırılması. Fırat Üniversitesi Sağlık Bilimleri Dergisi, 20: 221-22.

Tekelioglu O, Çimen M, Bayril T 2010. The Milk Biochemical Parameters Having Economic Importance in Machine Milked Cows. Journal of Animal and Veterinary Advances, 9(3): 519-521.

Tölü C, Yurtman IY, Savaş T 2010. Gökçeada, Malta ve Türk Saanen Keçi Genotiplerinin Süt Verim Özellikleri Bakımından Karşılaştırılması. Hayvansal Üretim, 51(1): 8-15.

Ulutaş Z, Kuran M, Şirin E, Aksoy Y 2010. Tokat Şartlarında Yetiştirilen Saanen Irkı Keçilerin Döl, Süt Verimi ve Oğlakların Gelişme Özelliklerinin Belirlenmesi. Ulusal Keçicilik Kongresi Bildiriler Kitabı, Çanakkale, 24-26 Haziran, 215-218.

Wang PQ 1989. Udder Characteristics in Toggenburg Dairy Goats. Small Ruminant Research, 2: 181-190. 